\title{
Clinical, radiological and patient-reported outcomes in intra-articular calcaneal fractures: Comparison of conservative and surgical treatment
}

\author{
Eklem içi kalkaneus kırıklarında klinik, radyolojik ve hasta raporlu sonuçlar: \\ Konservatif ve cerrahi tedavinin karşılaştırıması
}

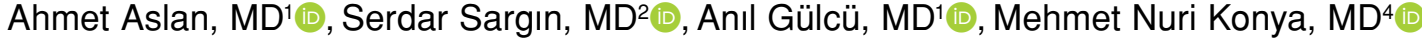 \\ 'Department of Orthopedics and Traumatology, Alanya Alaaddin Keykubat University, Faculty of Medicine, Antalya, Turkey \\ ${ }^{2}$ Department of Orthopedics and Traumatology, Balıkesir University Faculty of Medicine, Balıkesir, Turkey \\ ${ }^{3}$ Department of Orthopedics and Traumatology, Afyon Health Science University Faculty of Medicine, Afyonkarahisar, Turkey
}

\begin{abstract}
Objectives: This study aims to compare the radiological, clinical and patient-reported outcomes of patients with intra-articular calcaneus fractures treated conservatively or surgically.
\end{abstract}

Patients and methods: Fifty-four patients ( 30 males, 24 females; mean age 41.0 years; range, 18 to 73 years) treated due to calcaneus fracture were included in the study. Twenty-nine patients underwent conservative treatment (group 1) and 25 patients underwent surgical treatment (group 2). The fractures were classified according to Sanders. At the final follow-up, patients' Bohler's angle, The American Orthopedic Foot and Ankle Society (AOFAS) Ankle-Hindfoot Score and Foot Function Index (FFI) were used to evaluate their radiological, clinical and patient-reported outcomes. Postoperative complications were also noted.

Results: The fracture was at the right foot in 28 patients and the left foot in 26 patients. The mean follow-up duration was $41.1 \pm 23.2$ months (range, 24 to 126 months). No statistically significant differences were found between the groups in terms of gender, fracture side, mean age, or follow-up duration $(\mathrm{p}=0.951, \mathrm{p}=0.571, \mathrm{p}=0.326$, and $\mathrm{p}=0.620$, respectively). According to Sanders classification, 18 patients were type 2 and 11 patients were type 3 in group 1 , while 11 patients were type 2 and 14 patients were type 3 in group 2 . However, there was no statistically significant difference between the groups in terms of the type of the fracture $(\mathrm{p}=0.184)$. On the other hand, the outcomes were significantly better for group 2 compared to group 1 in terms of the Bohler's angle, AOFAS and FFI scores $(\mathrm{p}=0.004, \mathrm{p}=0.003$ and $\mathrm{p}=0.006$, respectively). In group 1, subtalar arthritis developed in three patients. In group 2, wound healing problems and superficial infection developed in three patients, while subtalar arthritis developed in two patients.

Conclusion: Surgical treatment is more effective in intra-articular calcaneus fractures compared to conservative treatment according to clinical, radiological and patient-reported outcomes. In addition, wound problems should be considered in surgical management.

Keywords: Bohler's angle, intra-articular calcaneus fracture, patient-reported outcomes, Sanders classification, subtalar arthritis, surgical treatment.
Öz

Amaç: Bu çalışmada konservatif veya cerrahi olarak tedavi edilen eklem içi kalkaneus kırıklı hastaların radyolojik, klinik ve hasta raporlu sonuçları karşılaştırıldı.

Hastalar ve yöntemler: Çalışmaya kalkaneus kırı̆̆ı nedeni ile tedavi edilen 54 hasta (30 erkek, 24 kadın; ort. yaş 41.0 yıl; dağılım, 18-73 yıl) dahil edildi. Yirmi dokuz hastaya konservatif tedavi (grup 1) ve 25 hastaya cerrahi tedavi (grup 2) uygulandı. Kırıklar Sanders'e göre sınıflandırıldı. Son takipte hastaların radyolojik, klinik ve hasta raporlu sonuçlarını değerlendirmek için Bohler açısı, Amerikan Ortopedik Ayak-Ayak Bileği Derneği (AOFAS) Ayak Bileği ve Arka Ayak Skoru ve Ayak Fonksiyon İndeksi (AFI) kullanıldı. Ameliyat sonrası komplikasyonlar da kaydedildi.

Bulgular: Yirmi sekiz hastada kırık sağ ayakta ve 26 hastada sol ayakta idi. Ortalama takip süresi $41.1 \pm 23.2$ ay (dağ $11 ı$, 24-126 ay) idi. Gruplar arasında cinsiyet, kırık tarafı, ortalama yaş ve takip süresi bakımından istatistiksel olarak anlamlı farklılık bulunmadı (sirasiyla, $\mathrm{p}=0.951, \mathrm{p}=0.571, \mathrm{p}=0.326$ ve $\mathrm{p}=0.620$ ). Sanders sinıflandırmasına göre, grup l'de 18 hasta tip 2 ve 11 hasta tip 3 iken grup 2'de 11 hasta tip 2 ve 14 hasta tip 3 idi. Ancak gruplar arasında kırık tipi açısından istatistiksel olarak anlamlı farklılık yoktu $(p=0.184)$. Diğer yandan; Bohler açısı, AOFAS ve AFI skorları bakımından sonuçlar grup 2 için grup 1'e kıyasla anlamlı olarak daha iyi idi (sırasıyla, $\mathrm{p}=0.004, \mathrm{p}=0.003$ ve $\mathrm{p}=0.006$ ). Grup 1 'de üç hastada subtalar artrit gelişti. Grup 2 'de üç hastada yara iyileşme sorunları ve yüzeyel enfeksiyon gelişirken iki hastada subtalar artrit gelişti.

Sonuç: Klinik, radyolojik ve hasta raporlu sonuçlara göre eklem içi kalkaneus kırıklarında cerrahi tedavi konservatif tedaviye kıyasla daha etkilidir. Bununla birlikte, cerrahi tedavide yara sorunlarına dikkat edilmelidir.

Anahtar sözcükler: Bohler açısı, eklem içi kalkaneus kırı̆̆ı, hasta raporlu sonuçlar, Sanders sınıflandırması, subtalar artrit, cerrahi tedavi.

Received: April 15, 2019 Accepted: May 21, 2019 Published online: June 13, 2019

Correspondence: Ahmet Aslan, MD. Alanya Alaaddin Keykubat Üniversitesi Alanya Eğitim ve Araștırma Hastanesi Ortopedi ve Travmatoloji Kliniği, 07425 Alanya, Antalya, Turkey. Tel: +90 505 - 6462411 e-mail: draaslan@hotmail.com 
Displaced intra-articular calcaneal fracture (DIACF) treatment represents a challenging and controversial issue in traumatology. ${ }^{[1,2]}$ Today, many orthopedic surgeons prefer surgical treatment for DIACF. In addition, the current literature supports the use of open reduction and internal fixation (ORIF). ${ }^{[2,3]}$ The advantages and disadvantages of conservative and surgical treatment have been reviewed in the literature. Some authors argue that the best results are obtained by surgical methods, while others advocate conservative treatment methods. ${ }^{[3]}$ A recent meta-analysis ${ }^{[4]}$ indicates the lack of sufficient quality data to determine which method is better for the treatment of DIACF. The debate on DIACF's optimal treatment and management continues, and despite randomized controlled trials, the literature, which offers contradictory recommendations, is still unclear. ${ }^{[5]}$ Therefore, in this study, we aimed to compare the radiological, clinical and patient-reported outcomes of patients with intraarticular calcaneal fractures treated conservatively or surgically.

\section{PATIENTS AND METHODS}

This study was conducted in our clinics and included 54 patients (30 males, 24 females; mean age 41.0 years; range, 18 to 73 years) who had been treated for calcaneal fractures between April 2009 and December 2015. Inclusion criteria were patients with Sanders type 2 or type 3 fractures, those with closed fractures, intra-articular fractures, patients admitted two weeks after injury, those with regular records and with at least two years of follow-up. Patients with inadequate data and follow-up, previous calcaneus surgery, foot deformity and arthrosis in the foot joints were excluded. In addition, type 1 and type 4 fractures were excluded for the following reasons: All type 1 fractures were treated conservatively, while type 4 fractures were usually treated surgically but they had concomitant ankle, vertebral and pelvic injuries which could affect the results. The study protocol was approved by the Balıkesir University Faculty of Medicine Ethics Committee (No: (2016-40). A written informed consent was obtained from each patient. The study was conducted in accordance with the principles of the Declaration of Helsinki.

This study was performed retrospectively, as a cross-sectional, non-randomized and multicenter work (at the study dates, in the clinics of authors staff in Kastamonu, Afyonkarahisar and Iğdır State Hospital and also Balıkesir Medical Faculty). All authors had sufficient experience in foot surgery. Patients were divided into two groups according to treatment. Group $1(\mathrm{n}=29)$ was treated conservatively with circular leg casts, while group 2 $(n=25)$ was treated surgically with plate and screw osteosynthesis. All patients were classified according to Sanders classification using preoperative computed tomography (CT) images. The patients were followed-up periodically by clinical and radiological evaluation. Identical postoperative rehabilitation protocol was applied for all patients. At the final control, patients were evaluated radiographically with Bohler's angle, the American Orthopedic Foot and Ankle Society (AOFAS) Ankle-Hindfoot Score and Foot Function Index (FFI) score as the patientreported outcome. In addition, complications in fracture healing such nonunion or malunion, soft tissue problems, infection and subtalar arthritis were noted.

Surgery was performed with attention to the soft tissue condition of the foot. In the presence of a soft tissue injury, wounds should be expected to heal and the edema should be expected to decrease. Patients with excessive edema were operated on the seventh day on average (range, 5 to 12 days), after the elevation and anti-edema treatment in order to avoid skin problems. The patient was positioned in lateral decubitus. Prophylactic antibiotherapy was administered. The surgical technique ${ }^{[6]}$ included an "L" shaped skin incision. The incision was full thickness from the skin to the bone. The flap, which contains the sural nerve, was retracted with three Kirschner wires (K-wires). The lateral wall of the calcaneus was reflected or removed to reach the medial wall and reduce it. The posterior tuberosity was manipulated using a Schanz screw and was provisionally stabilized with two K-wires inserted retrogradely. The superolateral articular fragment was reduced to the sustentacular fragment and temporarily fixed with K-wires. Finally, the anterior process and the calcaneo-cuboid joint were reduced by carefully replacing fracture lines on the floor of the sinus tarsi and dorsal aspect of the anterior process. Preliminary reduction was checked using lateral, axial and internal oblique views. The lateral wall was repositioned and a calcaneal plate was applied on lateral surface and fixed with screws. Intraoperative control radiographs were obtained. The wound was irrigated with saline solution and closed in two layers. A short leg cast was applied postoperatively with foot in plantigrade position until the wound was sealed. Afterwards, mobilization exercises were begun. Partial weight bearing was allowed after two months. ${ }^{[7,8]}$ 
As part of the conservative treatment protocol, after initial lateral, Broden, axial and internal oblique views, all were treated by closed reduction using the technique described by Omoto et al. ${ }^{[9]}$ which involves manually compressing the medial and lateral aspects of the calcaneum with the patient prone and sedated, with the knee flexed at $70^{\circ}$ and the ankle in the equinus position. After reduction and immobilization, all patients were hospitalized in order to monitor for swelling of the leg. Edema was treated by elevation, cold application and intramuscular injections of non-steroidal antiinflammatory drugs. If serious edema did not occur within seven days, we repeated the reduction maneuver with the patient sedated and applied a long leg cast with the ankle in $20^{\circ}$ of equines. After six weeks, the cast was changed to a below-knee cast to allow movement of the knee and after eight weeks, it was removed. Active movements of the ankle were started and the patients were instructed to wear silicone socks supported by metatarsal and medial longitudinal arches. Partial and full weight-bearing were encouraged at the end of the eighth and $12^{\text {th }}$ weeks, respectively. All patients were subsequently reviewed every three months for the first year and every six months thereafter. The same treatment protocol was applied and followed by all of the authors. ${ }^{[7]}$

Similar rehabilitation was applied to all patients. Patients were allowed partial weight-bearing for eight-10 weeks. Active and passive range of motion exercises were recommended. After observing clinical and radiological fracture union, exercises were started to strengthen the Achilles tendon and hamstring muscles.
All patients were classified according to Sanders classification using preoperative CT images. ${ }^{[6]}$ The functional status outcomes reported by patients were measured using the FFI. Foot Function Index has been used in many studies to measure the effect of pathological features of foot on the function in terms of pain, disability and activity ${ }^{[10,11]}$ In this index, 23 questions are scored from 1 (no pain, no trouble, always not present) to 10 (the worst pain imaginable, always very difficult or impossible); the maximum score can be 100 points, and higher score indicates more disability. ${ }^{[11]}$

The AOFAS Ankle-Hindfoot Scale was used to assess clinical outcomes. This scale contains nine questions about pain sub-areas (one question: 40 points), function (seven questions: 50 points) and consistency (one question: 10 points). The maximum score was $100 .^{[11,12]}$

\section{Statistical analysis}

Compliance with normal distribution was controlled by Kolmogorov-Smirnov test. For statistical analysis, chi-square test was used for categorical data, and Mann-Whitney $U$ test was used for continuous data. A $p$ value $<0.05$ was considered statistically significant.

The $G^{*}$ Power version 3.1 statistical analysis program (Heinrich-Heine-Universität Düsseldorf, Düsseldorf, Germany) was used to compute the study power. There were 29 participants in group 1 and 25 in group 2. If the allocation ratio, effect size (d) and alpha error probability were accepted as 1, 0.6 and 0.05 , respectively, hereby, the critical $t$ value would be 1.68 and power was found 0.70 .

TABLE I

Distribution and comparison of demographic data by groups

\begin{tabular}{|c|c|c|c|c|c|}
\hline \multirow[b]{2}{*}{ Parameter } & \multicolumn{2}{|c|}{$\begin{array}{c}\text { Group } 1 \\
\text { (Conservative, } \mathrm{n}=29 \text { ) }\end{array}$} & \multicolumn{2}{|c|}{$\begin{array}{c}\text { Group } 2 \\
\text { (Surgical, } n=25 \text { ) }\end{array}$} & \multirow[b]{2}{*}{$p$} \\
\hline & $n$ & Mean $\pm S D$ & $\mathrm{n}$ & Mean $\pm S D$ & \\
\hline Age (year) & & $42.6 \pm 12.3$ & & $39.2 \pm 10.8$ & $0.326^{\star *}$ \\
\hline Gender & & & & & $0.951^{*}$ \\
\hline Female & 13 & & 11 & & \\
\hline Male & 16 & & 14 & & \\
\hline Side & & & & & $0.571^{*}$ \\
\hline Right & 15 & & 14 & & \\
\hline Left & 14 & & 11 & & \\
\hline Sanders classification & & & & & $0.184^{*}$ \\
\hline II & 18 & & 11 & & \\
\hline III & 11 & & 14 & & \\
\hline Follow-up (month) & & $42.1 \pm 23.2$ & & $40.0 \pm 23.5$ & $0.620^{* *}$ \\
\hline
\end{tabular}




\section{TABLE II}

Outcomes of comparison of groups according to FFI, AOFAS and Bohler's angle

\begin{tabular}{|c|c|c|c|}
\hline & $\begin{array}{c}\text { Group } 1 \\
\text { (Conservative, } \mathrm{n}=29 \text { ) }\end{array}$ & $\begin{array}{c}\text { Group } 2 \\
\text { (Surgical, } \mathrm{n}=25 \text { ) }\end{array}$ & \\
\hline Parameter & Mean $\pm S D$ & Mean $\pm S D$ & $p$ \\
\hline $\mathrm{FFI}$ & $36.2 \pm 10.9$ & $28.7 \pm 8.3$ & $0.006^{*}$ \\
\hline AOFAS & $62.2 \pm 11.2$ & $72.4 \pm 12.9$ & $0.003^{\prime}$ \\
\hline Bohler's angle & $10.9 \pm 11.1$ & $20.0 \pm 10.9$ & $0.004^{*}$ \\
\hline
\end{tabular}

FFI: Foot Function Index; AOFAS: American Orthopedic Foot and Ankle Score; SD: Standard deviation; * Mann-Whitney U test.

\section{RESULTS}

The injury area was the right foot in 28 patients and the left foot in 26 patients. The mean follow-up duration of all patients was $41.1 \pm 23.2$ months (range, 24 to 126 months). No statistically significant difference was found between groups 1 and 2 in terms of gender, side, mean age and duration of follow-up ( $\mathrm{p}=0.951, \mathrm{p}=0.571, \mathrm{p}=0.326$, and $\mathrm{p}=0.620$, respectively) (Table I).

According to the Sanders classification, 18 patients had Sanders type 2 fractures and 11 patients had type 3 fractures in group 1 . In group 2, Sanders type 2 fractures were detected in 11 patients and type 3 fractures were detected in 14 patients. There was no statistically significant difference between the two groups in terms of Sanders classification $(\mathrm{p}=0.184)$.

Significantly better results were obtained for group 2 compared to group 1 in terms of the Bohler's angle, AOFAS and FFI scores $(\mathrm{p}=0.004, \mathrm{p}=0.003$, and $\mathrm{p}=0.006$, respectively) (Table II).

Superficial infection occurred in three patients in group 2 while deep infection and subtalar arthrosis occurred in one patient. In group 1, subtalar arthrosis occurred in three patients and ankle arthrosis developed in one patient. In addition, these four patients had calcaneal malunion, expansion of the calcaneus and loss of height. The patient who developed superficial infection was treated with oral antibiotherapy and wound care. The deep infection of the other patient improved with debridement and appropriate antibiotic treatment following removal of the implant. Some of our cases are presented in Figures 1 and 2.

\section{DISCUSSION}

The current literature comparing the results of surgical and conservative treatment of DIACF
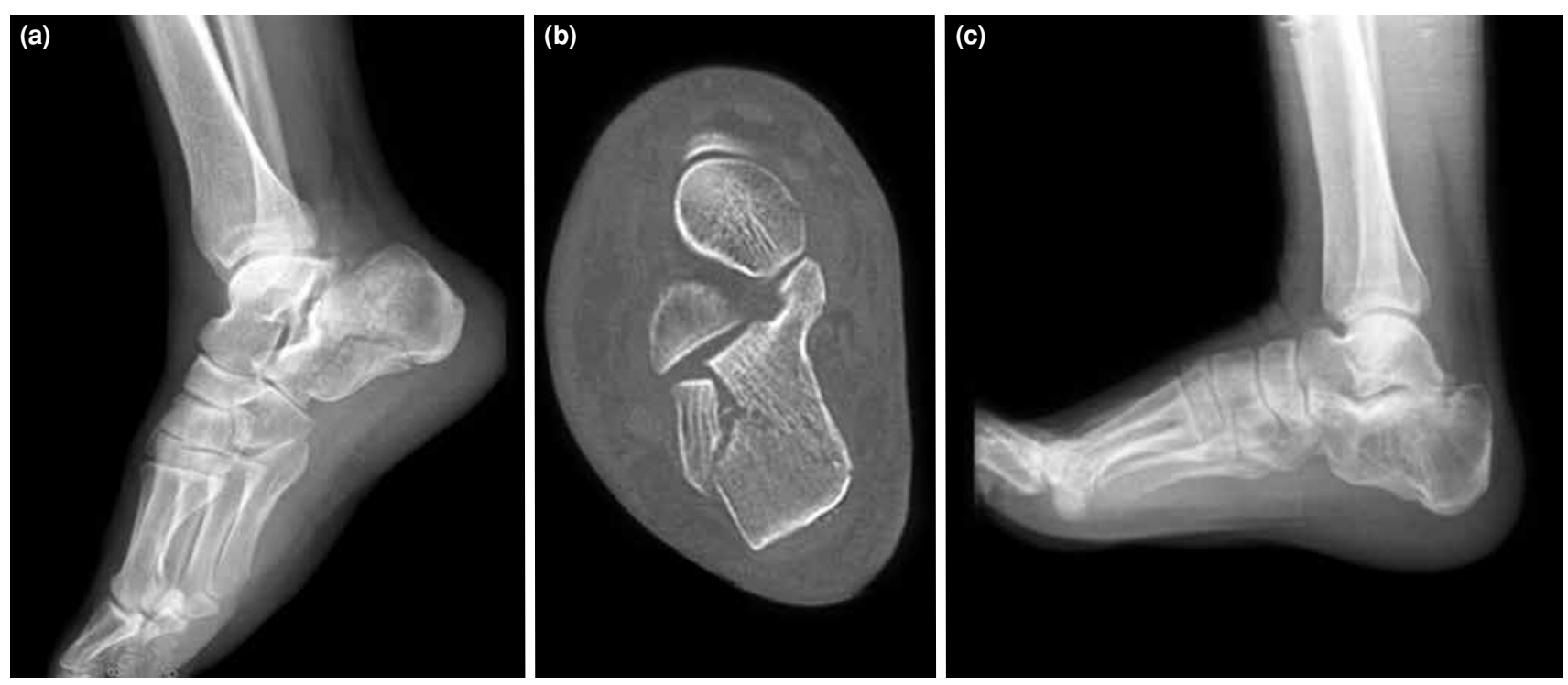

Figure 1. Initial lateral X-ray (a), computed tomography scan (b) and follow-up lateral X-ray (c) images of a conservatively treated patient, a 37-year-old male patient, right foot and Sanders type 2 fracture. 

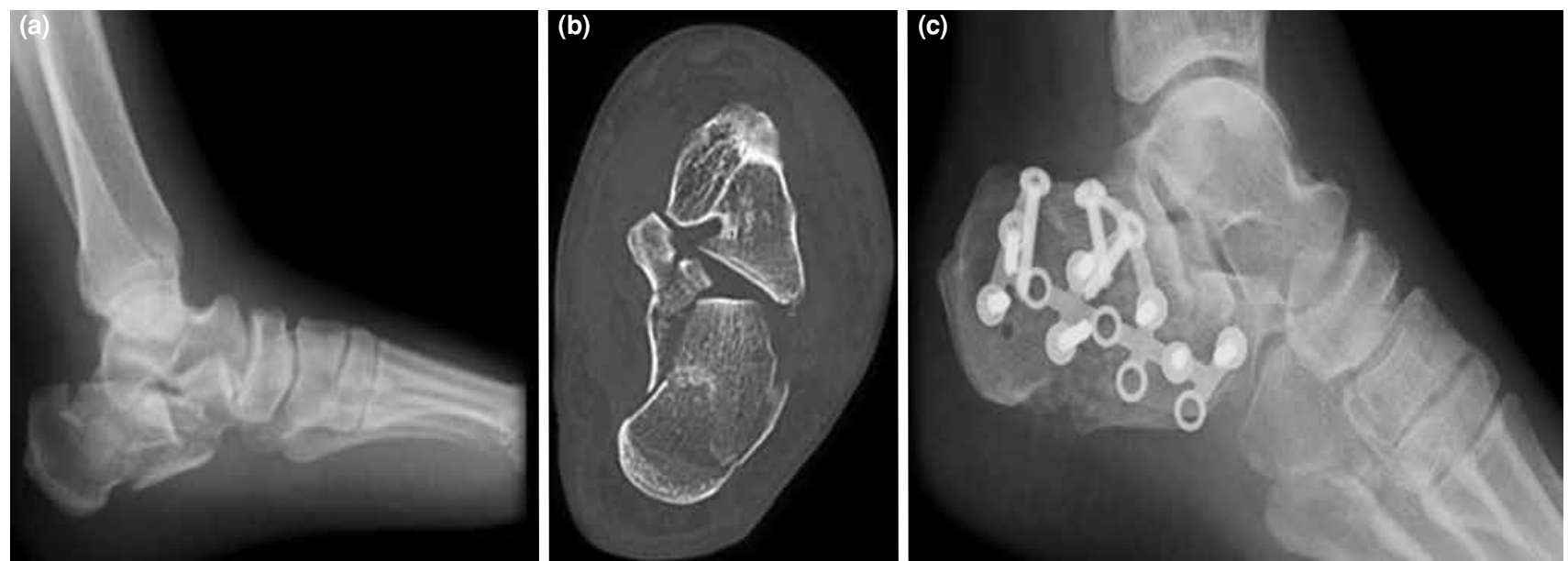

Figure 2. Preoperative lateral X-ray (a), computed tomography scan (b) and follow-up lateral X-ray (c) images of a surgically treated patient, a 50-year-old female patient, left foot and Sanders type 3 fracture.

revealed that clinical AOFAS scores of surgical treatment were higher. ${ }^{[13,14]}$ Melcher et al. ${ }^{[15]}$ reported excellent and good results in 16 patients who underwent surgical treatment and were followed-up for 10 years, despite radiographically detecting subtalar joint arthrosis. Gülabi et al. ${ }^{[16]}$ treated 27 feet of 26 patients with DICAFs by ORIF, and except for three patients, they achieved good and very good results in average 34.4 months of follow-up. However, in some studies comparing conservative and surgical treatments, no difference has been reported. Kundel et al. ${ }^{[17]}$ reported no difference between surgery and conservative treatment in the functional outcome of 63 patients with 10 years of follow-up, and reported further complications in patients treated surgically. Kennedy et al. ${ }^{[18]}$ stated that conservative treatment was safe, effective, and reported that its functional outcome was similar to surgical treatment.

In our study, no statistically significant difference was found between the groups according to Sanders classification in terms of fracture type, gender, side, mean age, and duration of follow-up ( $p>0.5$, Table I). However, AOFAS scores were higher ${ }^{[19]}$ in the surgical treatment group compared to the conservative treatment group in terms of clinical outcomes, and they were statistically significant $(\mathrm{p}=0.03$, Table II).

Some authors found the improvement of Bohler's angle in the surgical group treated with ORIF. Makki et al. ${ }^{[20]}$ concluded that restoration of Bohler's angle was associated with better functional outcome in 45 patients treated with ORIF, and that rapid osteosynthesis should be considered in DIACF in order to correct the angle of the hindfoot and the Bohler's angle. In conservative treatment of DICAFs, it should be taken into consideration that the Bohler's angle can be reduced to $11^{\circ}$ in the first year after trauma. ${ }^{[21]}$ In this study, Bohler's angle was significantly better in the surgical group in terms of radiological outcomes $(\mathrm{p}=0.004$, Table II).

In the literature, higher AOFAS scores have been reported in surgically treated patients, and patients have reported better FFI scores. ${ }^{[14]}$ Kulkarni et al. ${ }^{[22]}$ reported an acceptable complication rate in patients treated with ORIF in their study comparing the outcomes of patients who received surgical and conservative treatment, and reported good functional outcomes and higher patient satisfaction. In our study, patient-reported outcomes were significantly better in the surgical group in terms of FFI scores $(p=0.006$, Table II).

The most common complication is soft tissue problems particularly in surgical treatment. Other complications include malunion, posttraumatic subtalar osteoarthritis, chronic foot pain, peroneal tendonitis and lateral compression syndrome. ${ }^{[23]}$ Wound healing problems may occur in $16-25 \%$ of calcaneal fractures treated with ORIF. Complications of wound healing occur due to traumatic incisions performed. ${ }^{[2,3]}$ Gilani and Amin ${ }^{[1]}$ evaluated 42 patients in their non-randomized retrospective study and reported wound complications in the surgical group as two cases $(9.1 \%)$.

In this study, in the surgical group (group 2), wound site problems and superficial infection developed in three patients, while deep infection and subtalar arthritis developed in one patient. In the conservative group (group 1), subtalar arthrosis occurred in three patients, while posttraumatic ankle 
arthrosis developed in one patient. In addition, these four patients had calcaneal malunion, expansion of the calcaneus and loss of height.

The most important limitations of our study are its retrospective design and small sample size. Therefore, the power analysis may be rather low. The use of CT for joint reduction evaluation in the postoperative period and in the controls, and merely clinical and radiographic evaluation of patients may be considered as the other limitations of the study.

In conclusion, the results of this study indicate that surgical treatment of intra-articular calcaneus fractures allows more effective results compared to conservative treatment based on clinical, radiological and patient-reported outcomes. In addition, wound problems should be considered in surgical management. We believe that less complication rates and better surgical outcomes can be obtained with preoperative CT-guided good planning and careful timing according to the condition of the soft tissues, and proper surgical incision and technique.

\section{Declaration of conflicting interests}

The authors declared no conflicts of interest with respect to the authorship and/or publication of this article.

\section{Funding}

The authors received no financial support for the research and/or authorship of this article.

\section{REFERENCES}

1. Gilani SF, Amin MS. Operative treatment of displaced intra-articular fractures of Calcaneum: Is it worthwhile? J Pak Med Assoc 2014;64:161-6.

2. Gougoulias N, Khanna A, McBride DJ, Maffulli N. Management of calcaneal fractures: systematic review of randomized trials. Br Med Bull 2009;92:153-67.

3. Howard JL, Buckley R, McCormack R, Pate G, Leighton $\mathrm{R}$, Petrie $\mathrm{D}$, et al. Complications following management of displaced intra-articular calcaneal fractures: a prospective randomized trial comparing open reduction internal fixation with nonoperative management. J Orthop Trauma 2003;17:241-9.

4. Bruce J, Sutherland A. Surgical versus conservative interventions for displaced intra-articular calcaneal fractures. Cochrane Database Syst Rev 2013;1:CD008628.

5. Dhillon MS, Prabhakar S. Treatment of displaced intraarticular calcaneus fractures: a current concepts review. SICOT J 2017;3:59.

6. Sanders R, Fortin P, DiPasquale T, Walling A. Operative treatment in 120 displaced intraarticular calcaneal fractures. Results using a prognostic computed tomography scan classification. Clin Orthop Relat Res 1993;290:87-95.
7. Konya MN, Sargin S. Does Treatment Modality Affect Clinical Results of Calcaneal Fractures: A Retrospective Comparative Study. Acta Medica Alanya 2017;1:23-8.

8. Kınık H, Yıldız Y, Mergen E. Early and mid-term results of surgically treated intra-articular calcaneal fractures. Eklem Hastalik Cerrahisi 2001;12:2:161-8.

9. Omoto H, Sakurada K, Sugi M, Nakamura K. A new method of manual reduction for intra-articular fracture of the calcaneus. Clin Orthop Relat Res 1983;177:104-11.

10. De Boer AS, Van Lieshout EM, Den Hartog D, Weerts B, Verhofstad MH, Schepers T. Functional outcome and patient satisfaction after displaced intra-articular calcaneal fractures: a comparison among open, percutaneous, and nonoperative treatment. J Foot Ankle Surg 2015;54:298-305.

11. Budiman-Mak E, Conrad KJ, Roach KE. The Foot Function Index: a measure of foot pain and disability. J Clin Epidemiol 1991;44:561-70.

12. Ibrahim T, Beiri A, Azzabi M, Best AJ, Taylor GJ, Menon DK. Reliability and validity of the subjective component of the American Orthopaedic Foot and Ankle Society clinical rating scales. J Foot Ankle Surg 2007;46:65-74.

13. Veltman ES, Doornberg JN, Stufkens SA, Luitse JS, van den Bekerom MP. Long-term outcomes of 1,730 calcaneal fractures: systematic review of the literature. J Foot Ankle Surg 2013;52:486-90.

14. Thordarson DB, Krieger LE. Operative vs. nonoperative treatment of intra-articular fractures of the calcaneus: a prospective randomized trial. Foot Ankle Int 1996;17:2-9.

15. Melcher G, Degonda F, Leutenegger A, Rüedi T. Tenyear follow-up after operative treatment for intra-articular fractures of the calcaneus. J Trauma 1995;38:713-6.

16. Gülabi D, Sarı F, Sen C, Avcı CC, Sağlam F, Erdem M, et al. Mid-term results of calcaneal plating for displaced intraarticular calcaneus fractures. Ulus Travma Acil Cerrahi Derg 2013;19:145-51.

17. Kundel K, Funk E, Brutscher M, Bickel R. Calcaneal fractures: operative versus nonoperative treatment. J Trauma 1996;41:839-45.

18. Kennedy JG, Jan WM, McGuinness AJ, Barry K, Curtin J, Cashman WF, et al. An outcomes assessment of intraarticular calcaneal fractures, using patient and physician's assessment profiles. Injury 2003;34:932-6.

19. Atik OŞ. Which articles do we prefer to publish? Eklem Hastalik Cerrahisi 2018;29:1.

20. Makki D, Alnajjar HM, Walkay S, Ramkumar U, Watson AJ, Allen PW. Osteosynthesis of displaced intra-articular fractures of the calcaneum: a long-term review of 47 cases. J Bone Joint Surg [Br] 2010;92:693-700.

21. Bakker B, Halm JA, Van Lieshout EM, Schepers T. The fate of Böhler's angle in conservatively-treated displaced intraarticular calcaneal fractures. Int Orthop 2012;36:2495-9.

22. Kulkarni HG, Mane VS, Gaonkar KL, Patil PP, Shaha MS, Patel NS, et al. Plating for intra-articular calcaneal fractures.... Is it an overkill? J Clin Orthop Trauma 2015;6:153-9.

23. Rak V, Ira D, Masek M. Operative treatment of intraarticular calcaneal fractures with calcaneal plates and its complications. Indian J Orthop 2009;43:271-80. 